\title{
Leaving them behind: healthcare services in situations of armed conflict
}

GLOBAL HELSE

\section{FREDERIK FRANCOIS SIEM}

E-mail: frederik.siem@redcross.no

Frederik Francois Siem (born 1982) has a BA in Social Anthropology and Religion from the School of Oriental and African Studies (SOAS), University of London, UK and an MA in Conflict Resolution from Georgetown University, USA. He currently works with the Norwegian Red Cross on the protection of healthcare services, as a Senior Adviser for Health Care in Danger.

The author has completed the ICMJE form and reports no conflicts of interest.

In the 2030 Agenda for Sustainable Development in 2016, the international community agreed to 'leave no one behind'. However, the community is doing precisely that by failing to act as millions living in conflict-affected areas are deprived of access to healthcare services. The few healthcare services operating in these situations are attacked with impunity. We need to seek new ways to protect healthcare workers operating in armed conflicts.

In times of conflict, the number of persons in need of emergency medical care increases substantially. People are wounded in attacks, while deterioration in living conditions increases the number of sick. A lack of access to food, clean water, adequate sanitation, shelter and other basic necessities increases the affected population's exposure to infection and disease. A review of nine armed conflicts in sub-Saharan Africa concluded that deaths in battle accounted on average for $6-8 \%$ of deaths, while the vast majority of deaths were caused by disease and malnutrition (1). Additionally, the capacity of the healthcare system is weakened by disruptions in the supply chains, the lack of a continuous electricity or water supply, and fewer available healthcare workers.

It is a sad irony that help is most difficult to provide precisely where it is most sorely needed. Healthcare delivery is also the subject of attacks, further widening the gap between needs and capacity. Humanitarian agencies attempt to fill this gap with rapid life-saving activities but are often faced with issues related to access, security and funding. Development actors, with their more sustainable, long-term approach, are seldom present in the midst of conflict. In order to close this yawning gap, the global health community needs to strengthen the respect for and protection of impartial healthcare services. Additionally, development actors need to engage responsibly in the midst of conflict, to ensure the continued functioning of the healthcare system. 


\section{Impact of conflict on healthcare systems}

Collapsing healthcare systems in times of conflict result in massive human and financial costs both during and after the conflict. These include excess mortality among patients with chronic diseases, permanent disabilities for people with traumatic injuries, higher rates of maternal and infant mortality, outbreaks of vaccine-preventable diseases and psychological trauma (2). It is therefore unsurprising that countries that have made progress towards reaching national health goals will most likely see it reversed if armed conflict occurs (3).

Additionally, the above-mentioned consequences are not confined to a particular territory. Syria's ongoing conflict and healthcare crisis has substantially increased the risk of infectious diseases becoming an epidemic beyond the geopolitical borders of the conflict itself (4). Nor are these consequences time-bound to ongoing hostilities. During a typical five-year conflict, infant mortality rates not only increase by $13 \%$ during the conflict; they remain at an $11 \%$ higher rate than the baseline for the first five years thereafter (5).

Beyond mortality, an estimated eight million disability-adjusted life years (DALYs) were lost in the year 1999 from civil wars that occurred during the period 1991-97 (6). The public health consequences of conflict can in fact persist for up to ten years after hostilities cease (7).

One might be encouraged by the mantras of the Sustainable Development Goals (SDGs) to 'leave no one behind' and 'to reach those furthest behind first', as they suggest an emphasis on hard-to-reach areas including those ravaged by conflict. In reality, however, resources dedicated to developing healthcare systems are more likely to be invested in times of peace, when issues related to security or access are less likely. Consequently, non-conflict-affected regions receive almost $60 \%$ more funding for reproductive health than conflict-affected regions (8). Given that the poor and their health are disproportionately affected by conflict and that the share of the world's poor living in fragile and conflict-affected situations is projected to reach $46 \%$ by 2030 (9), conflict-affected regions must receive more support if we are to 'ensure healthy lives and promote well-being for all at all ages' (SDG 3 ).

The consequences of this lack of engagement are compounded by the fact that the existing healthcare services are increasingly attacked during situations of armed conflict. Between 2012 and 2013, the International Committee of the Red Cross (ICRC) recorded 1809 violent incidents from 23 countries (10), and 2398 incidents from 11 countries between 2012 and 2014 (11). The reports reveal patterns of insecurity covering a wide range of acts that hinder the delivery of healthcare - from direct attacks against patients and health facilities, to arrests and kidnapping of health personnel, major delays at checkpoints and the looting of facilities. Furthermore, while such attacks cause immediate harm, they also have longerlasting effects as thousands of future patients may be deprived of treatment as a result.

\section{Protecting access to and delivery of healthcare services}

In response to the increasing number of attacks against healthcare services, the Red Cross and Red Crescent Movement launched an initiative known as 'Health Care in Danger' (HCiD). In 2011, it called on the ICRC to initiate expert consultations to formulate practical recommendations for making the delivery of health care safer in armed conflict or other emergencies. Thus, there is a considerable amount of guidance available for how states, healthcare facilities, ambulance services, militaries, armed groups and others can contribute to safer access to and delivery of healthcare services (12).

Nevertheless, the fundamental and non-derogable human right to access immediate and necessary health care, as stated in article 12 of the UN Covenant on Economic, Social and Cultural Rights (13), is constantly violated. Practical solutions may indeed have been developed, but the political will to implement them is often limited to conference halls in Geneva or New York and the political cost of attacks on healthcare services is disappointingly low. States must be held accountable for their implementation of the resolutions that they have voted for, such as the United Nations Security Council (UNSC) 
Resolution 2286, which demanded an end to impunity for those responsible for attacks against healthcare services and respect for international law on the part of all warring parties (14). Norway has already shown strong initiative, including by presenting a resolution for the protection of health workers at the United Nations General Assembly (UNGA) in 2014 (15), but could also envisage following this up in its bilateral dialogue with other states. For example, bilateral aid agreements could include commitments to strengthen and implement domestic legislation that reflects the state's international obligations with regard to safeguarding the access to and delivery of health care.

Norwegian bilateral or multilateral funding for healthcare systems should ideally always include elements related to the protection of these systems against attacks. The establishment of mechanisms to record threats, obstructions and attacks against healthcare providers and patients would constitute a good starting point. Such data can in turn inform the selection of the measures taken by the state to safeguard access to and delivery of healthcare services. They will also be useful in monitoring the barriers to progress towards reaching SDG 3. Unfortunately, while the implementation of national data collection mechanisms has already been called for by the World Health Assembly in 2012 (16), in the UNGA resolution put forward by Norway in 2014, and the UNSC resolution 2286 passed in 2016 (14), there are very few examples of such initiatives being undertaken.

Other approaches to generating accountability exist that do not rely on the state. Another powerful avenue could be to pair hospitals operating in conflict situations with hospitals in countries that can influence the parties to the conflict An attack on a partner hospital can result in an effective domestic outcry from the partner hospital within the country of influence, thus raising the political cost of allowing allies to target healthcare services.

\section{Maintaining healthcare services in situations of armed conflict}

Beyond strengthening the protection of healthcare services, the healthcare system should also be supported so that it can function at the required capacity. For such an endeavour to succeed, a stronger investment on the part of development institutions is needed during the conflict itself and not just in the post-conflict reconstruction phase. Allowing massive setbacks in healthcare development in times of conflict, including through neglect, prevents SDG 3 from ever being 'sustainable'.

Presently, states and development institutions are not actually compelled to 'help those furthest behind first' in accordance with the SDGs' pledge. Existing global health initiatives do, however, have the potential to promote greater accountability in the future. One such example is the proposal for a Framework Convention on Global Health (FCGH). Based on the right to health with a national and international funding framework and a special concern for marginalised populations, the FCGH would be a treaty aimed at eliminating global health inequities, providing standards to ensure health care and underlying determinants of health for all (17). This could help to promote investment in healthcare service delivery for those marginalised by conflict or violence. In addition, states could use such a convention to leverage a fairer distribution of global health resources to conflictaffected regions through the agencies where they are well represented. Norway, for instance, would be in a position to promote fairer funding prioritisation in the World Health Organization, the Global Alliance for Vaccines and Immunizations (GAVI) or the Global Fund to fight AIDS, Tuberculosis and Malaria.

An intended fairer distribution of resources does not, however, automatically result in universal coverage, meaning access to health services of sufficient quality to be effective without exposure to financial hardship (18). Security and access would still remain major challenges to reaching communities in need of healthcare in situations of armed conflict. 


\section{Engagement with armed groups}

The overwhelming majority of today's armed conflicts are not between states, but within states between armed forces and armed groups, or between various armed groups. Traditionally, the presence of armed groups is seen as a barrier to the safe implementation of humanitarian and development activities.

However, while armed groups can be perpetrators of attacks or obstruction, they are also beneficiaries of services, facilitators of access to services and at times service providers. To name a few examples of the latter, some Al Qaeda among the Maghreb's (AQIM) members have nursing skills, Hezbollah has its own ambulance service and the Revolutionary Armed Forces of Colombia (FARC) have developed a sophisticated health service (19).

In addition, whilst there is a contended lack of knowledge and ownership of the formal rules of International Humanitarian Law by armed groups, many of them do in fact have regulations, codes of conduct and behavioural patterns that reflect adherence to humanitarian norms, such as the respect for health care.In other words, engagement with armed groups can help overcome barriers to strengthening healthcare provision in hard-toreach areas.

Outdated stereotypes of armed groups result in lost opportunities to reduce suffering and the loss of lives. In some contexts, the state criminalises any form of support (including medical) to the areas under the armed group's control. This criminalisation clearly prioritises matters of national security over universal health coverage. Ironically though, preventing medical resources from flowing into areas under the control of armed groups can also adversely affect national security as it increases the risk of infectious disease outbreaks not being contained and spreading beyond conflict zones.

Armed groups do not cease to exist as a consequence of their marginalisation by governments, and any meaningful attempt at universal health coverage in conflict-affected regions will need to include them in one way or another. How to approach and involve these actors of influence is highly contextual and dependent on the characteristics of the groups themselves. One thing is certain: with regard to reducing attacks against healthcare services and closing the gap between healthcare needs and capacity in situations of armed conflict, armed groups are part of the problem and need to be part of any significant solution that is sustainable in the long term.

\section{Salvaging yesterday's developments for tomorrow's sustainability}

The current global health and development architecture is not equipped to deliver on the promises to 'leave no one behind' and 'to reach those furthest behind first'. Additionally, the few services able to operate in the midst of conflict are directly and indirectly attacked, further reducing the sorely needed health capacity. Political incentives to safeguard the healthcare system at the national level must be strengthened, as must incentives for development actors to support existing healthcare capacity during the conflict.

In conflict settings, tomorrow's development starts with what we are able to salvage today. It requires all actors of influence to seek new ways of both maintaining and protecting healthcare systems in situations of armed conflict.

\footnotetext{
REFERENCES:

1. Mack A, red. Human security report. New York: Oxford University Press, 2005; 127.

2. Kherallah M, Alahfez T, Sahloul Z et al. Health care in Syria before and during the crisis. Avicenna J

Med 2012; 2: 51 -3. [PubMed][CrossRef]

3. The World Bank. Twenty fragile states make progress on millennium development goals, 2013.
} 
http://www.worldbank.org/en/news/press-release/2013/05/o1/twenty-fragile-states-make-progress-on-m illennium-development-goals (22.5.2017).

4. Sharara SL, Kanj SS. War and infectious diseases: challenges of the Syrian civil war. PLoS Pathog 2014; 10: e1004438. [PubMed][CrossRef]

5. Collier P, Elliot VL, Håvard H et al. Breaking the conflict trap: Civil war and development policy. Washington DC: World Bank and Oxford University Press, 2003: 23-4.

6. Ghobarah HA, Huth P, Russet B. Civil wars kill and maim people-long after the shooting stops. Am Polit Sci Rev 2003; 97: 189. [CrossRef]

7. Mack A, red. Human security report. New York: Oxford University Press, 2005: 131.

8. Patel P, Dahab M, Tanabe M et al. Tracking official development assistance for reproductive health in conflict-affected countries: 2002-2011. BJOG 2016; 123: 1693 - 704. [PubMed][CrossRef]

9. The World Bank. Helping countries navigate a volatile environment, 2017. http://www.worldbank.org/en/topic/fragilityconflictviolence/overview (9.6.2017).

10. International Committee of the Red Cross. Health care in danger: Violent incidents affecting the delivery of healthcare, january 2012 to december 2013, 2014.

https://www.icrc.org/fre/assets/files/publications/icrc-002-4196.pdf(13.6.2017).

11. International Committee of the Red Cross. Health care in danger: Violent incidents affecting the delivery of healthcare, january 2012 to december 2014, 2014.

https://www.icrc.org/en/publication/4237-health-care-danger-violent-incidents-affecting-delivery-healt h-care-january-2012 (13.6.2017).

12. International Committee of the Red Cross. Health care in danger.

http://healthcareindanger.org/resource-centre/(9.6.2017).

13. United Nations. International covenant on economic, social and cultural rights.

http://www.ohchr.org/EN/ProfessionalInterest/Pages/CESCR.aspx (9.6.2017).

14. United Nations. Resolution 2286 (2016). https://www.un.org/en/ga/search/view_doc.asp?symbolS/RES/2286(2016) (4.7.2017).

15. United Nations. Resolution adopted by the General Assembly on 11 December 2014. https://www.un.org/en/ga/search/view_doc.asp?symbolA/RES/69/132 (3.7.2017).

16. Sixty-fifth world health assembly, 26 May 2012. WHO's response, and role as the health cluster lead, in meeting the growing demands of health in humanitarian emergencies.

http://apps.who.int/gb/ebwha/pdf_files/WHA65/A65_R2o-en.pdf(9.6.2017).

17. Platform for a Framework Convention on Global Health. http://www.globalhealthtreaty.org/ (9.6.2017)

18. World Health Organization. Health financing for universal coverage.

http://www.who.int/health_financing/universal_coverage_definition/en/(9.6.2017)

19. Norwegian Red Cross. Seminar report: Armed groups and access to health care in conflict areas.

Oslo: Norwegian Red Cross, 2015.

Published: 18 September 2017. Tidsskr Nor Legeforen. DOI: 10.4045/tidsskr.17.0524

Received 13.6.2017, first revision submitted 4.7.2017, accepted 7.8.2017.

(C) The Journal of the Norwegian Medical Association 2020. Downloaded from tidsskriftet.no 